http://journal.uinsgd.ac.id/index.php/biodjati

\title{
ANTIOXIDANT, ANTIBACTERIAL ACTIVITY AND GC-MS ANALYSIS OF EXTRACT OF GIANT FOREST ANT Dinomyrmex gigas (Latreille, 1802)
}

\author{
Evana $^{* 1}$, Praptiwi ${ }^{2}$, Ahmad Fathoni ${ }^{3}$, Oscar Efendi ${ }^{4}$, Andria Agusta ${ }^{5}$
}

Received : July 26, 2019

Accepted : November 03, 2019

DOI: 10.15575/biodjati.v4i2.5440

1,2,3,4,5 Research Center for Biology, Indonesian Institute of Sciences

Jl. Raya Jakarta-Bogor Km. 46, Cibinong, Bogor 16911, Indonesia

e-mail:

*1evana3009@gmail.com

${ }^{2}$ praptiwip@yahoo.com

3athoni.chem@gmail.com

${ }^{4}$ oscar.efendy@gmail.com

5andr002@lipi.go.id

*Corresponding author
Abstract. Giant forest ant Dinomyrmex gigas is one of the largest ants species in the world, native to the rain forests of Southeast Asia. It is known that ants have glands that produce chemical compounds that inhibit the growth of microbes. Therefore, it is necessary to determine the antioxidant and antibacterial activities as well as identify the chemical compounds of D. gigas extract. D. gigas was extracted successively with n-hexane, ethanol and methanol. The antioxidant activity was evaluated by determination of the half-maximal inhibitory concentration $\left(I C_{50}\right)$ values while the antibacterial activities of the extracts were determined by measuring the minimum inhibitory concentration (MIC). The results exhibited that the ICso values of n-hexane, ethanolic and methanolic extracts were 336.18 \pm 0.0984 , $89.16 \pm 0.0219$ and $90.72 \pm 0.0894 \mu \mathrm{g} / \mathrm{mL}$ respectively. The ethanolic extract exhibited the highest AAI value (0.34) followed by methanolic extract (0.33) and n-hexane extract (0.09). Based on AAI values, the extracts were classified as moderate antioxidants. The best MIC values were $625 \mu \mathrm{g} / \mathrm{mL}$ for both ethanolic and methanolic extracts against $S$. aureus, while MIC values of all extracts against E. coli were $>625 \mu \mathrm{g} / \mathrm{mL}$. Based on MIC values, all of the extracts presented weak activity against both $S$. aureus and E.coli. The GCMS analysis showed that there are up to 30 compounds constructed of the ethanolic extract. Three major compounds are ethyl oleate (29.78\%), n-hexadecanoic acid (17.54\%) and oleic acid (10.65\%).

Keywords: ant, antibacterial, antioxidant, Dinomyrmex gigas

\section{Citation}

Evana, Praptiwi, Fathoni, A., Efendi, O. \& Agusta, A. (2019). Antioxidant, Antibacterial Activity and GC-MS Analysis of Extract of Giant Forest Ant Dinomyrmex gigas (Latreille, 1802). Jurnal Biodjati, 4(2), 263-277

\section{INTRODUCTION}

In recent years, the search for new antibacterial sources becomes very important because the resistance of pathogenic bacteria to antibacterial agents has increased significantly. The search for natural antioxidants also gain a lot of attention, this is due to several advantages that natural antioxidants have com- pared to synthetic antioxidants, namely easy to obtain and have little or insignificant side effects as well as more economically valuable (Vicas et al., 2012). Studies on the medicinal use derived from animals, especially insects have been neglected when compared to plants (Wilsanand et al., 2007). Insects have been well known to live in humid environments that support the growth of pathogenic micro- 


\section{JURNAL BIDDJATI}

http://journal.uinsgd.ac.id/index.php/biodjati

organisms. They have evolved some defense mechanisms against diseases to protect their colonies. One of the defense mechanisms is by producing antimicrobial compounds (Stow \& Beattie, 2008), this makes insects as a promising source of new antibiotics (Mendonca et al., 2009; Zeng et al., 2016).

Ants are one of the genus of insects that are considered to be able to produce potent antimicrobial compounds. Based on previous researches by Bot et al. (2002) and Marin et al. (2006), it indicated that one of the primary sources of antimicrobial compounds in various ant species was the metapleural gland. Besides phenolic compounds and carboxylic acids, fatty acids are the major chemical compounds of metapleural gland secretions (Yek \& Mueller, 2011). The metapleural gland in Crematogaster deformis contains a mixture of phenol which has antiseptic properties.

The metapleural glands in some ant lineages (Dinomyrmex (Camponotus), Oecophylla and Polyrhachis) have been lost (Johnson et al., 2003), several of these ants lineages have developed the proficiency to generate antimicrobial compounds through other glands. The venom glands in some ant species have been identified as a source of antifungal and antibacterial. Ants of subfamily Formicinae, includes Dinomyrmex produce formic acid in their venom glands which are used for defense against vertebrates and other insects, that could also be used to inhibit the growth of fungi (Falotico et al., 2007; Tragust et al., 2013; Tranter \& Hughes, 2015). Solenopsins use venom glands to inhibit the growth of Streptococcus pneumoniae, Staphylococcus aureus and Enterococcus faecalis (Sullivan et al., 2009). Stinging ants usually use venom glands contain alkaloids, and peptides that possess antimicrobial properties (Moreau, 2013). The growth of both E. coli and S. aureus can be inhibited by peptides in Myrmecia pilosula's venom glands (Inagaki et al., 2004), while ants that do not have stingers, such as ants of the subfamily Dolichoderinae produce antimicrobial compounds from the pygidial glands.

Besides producing compounds that inhibit microbial growth, some of the ants may also have insecticidal activity (Orivel et al., 2001), antitumor against breast cancer cells (Badr et al., 2012), antioxidant (Ebaid et al., 2014), hypolipidemic effects and anti-inflammatory (Ebaid et al., 2012). Therefore, the bioactivity of ants extracts as antioxidant and antimicrobial needs to be examined, since antibacterial and antioxidant compounds have a fundamental role in preserving and intensifying the quality of human life.

Giant forest ant Dinomyrmex gigas (Latreille, 1802), (Figure 1) is one of the largest ants species in the world, native to the rain forests of Southeast Asia. The smallest D. gigas has a head width of $3.56 \mathrm{~mm}$ with a weight of $135 \mathrm{mg}$, and the largest has a head width of $6.9 \mathrm{~mm}$ and weighs $372 \mathrm{mg}$ (Pfeiffer \& Linsenmair, 2007). To the best of our knowledge, D. gigas extract has not been investigated to examine the antioxidant and antibacterial activities as well as the identification of their chemical compounds. Based on that reason, it is crucial to investigate their properties.

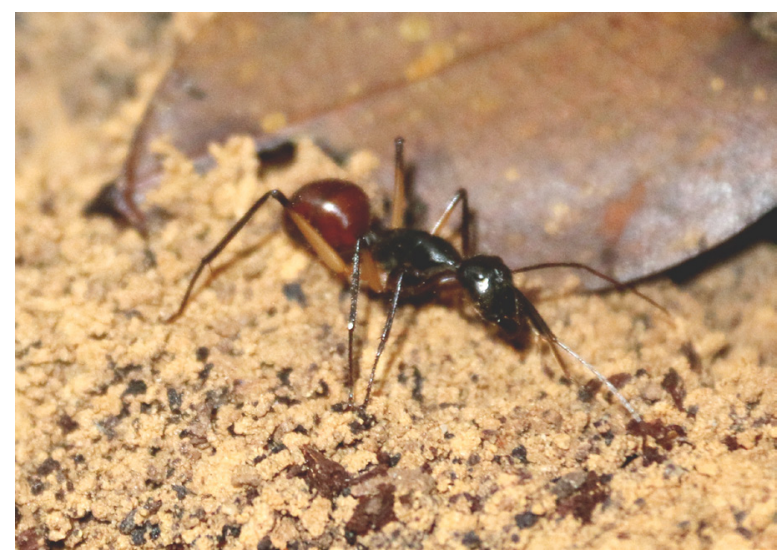

Figure 1. Giant Forest Ant Dinomyrmex gigas (Latreille, 1802) 


\section{JURNAL BIDDJATI}

http://journal.uinsgd.ac.id/index.php/biodjati

\section{MATERIALS AND METHODS}

\section{Sample Collection}

Colonies of D. gigas were collected from Bangkirai Hill, East Kalimantan in September 2018. The major workers approximately $28-30 \mathrm{~mm}$ in length. Identification was carried out at the Museum Zoologicum Bogoriense, Research Center for Biology-Indonesian Institute of Sciences.

\section{Sample Extraction}

One hundred grams of $D$. gigas were crushed and extracted with n-hexane, ethanol and methanol ( 3 x 24 hours) respectively. The filtrates of each solvent were collected and dried utilizing a rotary evaporator at $35^{\circ} \mathrm{C}$ to gain a crude extract, and the yield was determined.

\section{Chemical Compounds Analysis by Thin Layer Chromatography (TLC)}

The analysis of chemical compounds of D. gigas extracts was carried out by TLC. Ten microliters of $n$-hexane extract with a concentration of $10 \mathrm{mg} / \mathrm{mL}$ were transferred to the TLC silica plate (Merck F254) and developed with an eluent system of hexane:ethyl acetate (9:1). Separated chemical compounds were observed under UV light (254 nm), and followed by spraying with color reagent ( $1 \%$ vanillin-sulphuric acid and $1 \%$ cerium (IV) sulfate). The ethanolic and methanolic extracts were developed with an eluent system of chloroform:methanol:water $(6: 4: 1)$.

\section{Antioxidant Activity Assay}

The antioxidant activity assay was carried out by the TLC-bioautography method (Wang et al., 2012). Ten microliters of the extract with a concentration of 10 $\mathrm{mg} / \mathrm{mL}$ were transferred to the TLC silica plate and sprayed with a solution of $0.2 \%$ 2,2-diphenyl-1-picrylhydrazyl (DPPH) in methanol. (+)-Catechin (Sigma-Aldrich) was used as a positive control. The yellow spot against the purple background after spraying with DPPH reagent indicated the antioxidant activity.

\section{Determination of IC $_{50}$ Value and Antioxi- dant Activity Index (AAI)}

The $\mathrm{IC}_{50}$ value of extracts was carried out by serial microdilution using a 96-well microplate (Takao et al., 2015). The wells of column A was filled with $180 \mu \mathrm{L}$ of methanol p.a. and $20 \mu \mathrm{L}$ of extract $(10240 \mu \mathrm{g} / \mathrm{mL}$ in DMSO) and mixed thoroughly. Then, 100 $\mu \mathrm{L}$ of methanol p.a was filled in the wells of column B through $\mathrm{H}$. The serial dilution was undertaken with an appropriate final concentration of $512 \mu \mathrm{g} / \mathrm{mL}$. After finish diluting, each well was added with $100 \mu \mathrm{L}$ of DPPH solution with a concentration of $61.50 \mu \mathrm{g} / \mathrm{mL}$. The assay was performed in triplicate. The plates were incubated for 90 minutes under dark conditions at room temperature and the absorbances of the extracts were measured at $517 \mathrm{~nm}$ (Varioscan flash, Thermo scientific). The following equation was used to calculate the AAI (Scherer \& Godoy, 2009):

$$
\mathrm{AAI}=\frac{\text { The final concentration of DPPH in the reaction }(\mu \mathrm{g} / \mathrm{ml})}{\mathrm{IC}_{50}(\mu \mathrm{g} / \mathrm{ml})}
$$

The inhibitory concentration (IC) was calculated using the following equation:

$$
\operatorname{IC}(\%)=\frac{\left(A_{o}\right)-\left(A_{s}\right)}{\left(A_{o}\right)} \times 100 \%
$$

where, Ao and As are the absorbances of the negative control and the sample at different concentrations, respectively. 


\section{JURNAL BIDDJATI}

http://journal.uinsgd.ac.id/index.php/biodjati

\section{Antibacterial Activity Assay}

The antibacterial activity assay was carried out by the TLC-bioautography method (Dewanjee et al., 2015). Reference bacterial strains were Staphylococcus aureus Ina-CC B4 and Escherichia coli Ina-CC B5. Ten microliters of the extract with a concentration of $10 \mathrm{mg} / \mathrm{mL}$ were transferred to the TLC silica plate, then it was dipped into bacterial suspension in Mueller-Hinton Broth. The TLC plate was incubated under the humid condition at $37^{\circ} \mathrm{C}$ for $18 \mathrm{~h}$ and sprayed with a solution of p-iodonitrotetrazolium (INT) $4 \mathrm{mg} / \mathrm{mL}$. The inhibition of bacterial growth was indicated by the formation of clear white zones around the extract. Chloramphenicol was used as a positive control.

\section{Determination of Minimum Inhibitory Concentration (MIC)}

The MIC value of extracts was carried out by serial microdilution using a 96-well microplate (Pessini et al., 2003). The wells of column A was filled with double-strength of MHB $(100 \mu \mathrm{L}), 90 \mu \mathrm{L}$ of distilled water and $10 \mu \mathrm{L}$ of extract $(25000 \mu \mathrm{g} / \mathrm{mL}$ in DMSO), and mixed thoroughly. Then, a total of 100 $\mu \mathrm{L}$ of MHB was filled in columns B through $H$. The serial dilution was undertaken with an appropriate final concentration of $625 \mu \mathrm{g} /$ $\mathrm{mL}$. After finish diluting, each well was added with $100 \mu \mathrm{L}$ of bacterial suspension $\left(10^{5}\right.$ $\mathrm{CFU} / \mathrm{mL}$ ). The assay was performed in triplicate. After 18 hours of incubation at $37^{\circ} \mathrm{C}, 10$ $\mu \mathrm{L}$ of INT with a concentration of $4 \mathrm{mg} / \mathrm{mL}$ was added to each well. The color change to red indicates the presence of bacterial growth after added with the INT solution.

\section{Gas Chromatography-Mass Spectrometry (GC-MS) Analysis}

The GC-MS analysis was performed using a GC-MS QP 2010 Ultra (Shimadzu,
Japan). An exact quantity of six microliters of the extract with a concentration of $1 \mathrm{mg} /$ $\mathrm{mL}$ was injected. The chromatographic separation was performed on an Rtx-5-MS column (30 m x $0.25 \mathrm{~mm} \times 0.25 \mu \mathrm{m}$, RESTEK, USA) with a flow rate of Helium at $2 \mathrm{~mL} / \mathrm{min}$ and initial pressure was $121.1 \mathrm{kPa}$. The injector temperature was $230^{\circ} \mathrm{C}$, and then applying for the column temperature program as follows: $50^{\circ} \mathrm{C}$ for $5 \mathrm{~min}, 150^{\circ} \mathrm{C}$ at the rate of $10^{\circ} \mathrm{C} /$ min and then $250^{\circ} \mathrm{C}$ for $15 \mathrm{~min}$. The chemical compounds of extract were identified by comparing the mass spectra with the database of NIST 11 (National Institute Standard and Technology, US) and WILEY 8.

\section{RESULTS AND DISCUSSION}

The results of this study indicated that the solvent of extraction influence the yield of extracts. The maceration method was used due to its simple treatment and avoiding damage to the active compounds of $D$. gigas that are not resistant to high temperatures during the separation process. The percentage yield of the methanolic extract was found to be the highest $(1.948 \%)$, followed by ethanolic extract $(0.225 \%)$ and $n$-hexane extract $(0.0129 \%)$.

\section{Analysis of the Chemical Compounds of the Extracts by TLC}

The chromatogram profile of $D . g i-$ gas extract with different solvents provided a different chromatogram pattern (Figure 2). Most aromatic molecules or molecules that have conjugated double bonds appear as dark stain spots against the bright-green background on short-waved UV light (254 $\mathrm{nm})$. The formation of different colored stain spots after the TLC plate was sprayed with vanillin sulphuric acid and cerium (IV) sulfate as a color reagent indicates the presence of various chemical compounds in each ex- 


\section{JURNAL BIDDJATI}

http://journal.uinsgd.ac.id/index.php/biodjati

tract. Different retention factors on several stain spots indicate that the crude extract of D. gigas contained several chemical compounds. The compounds that have the same physical properties as the mobile phase will be retained longer in the mobile phase.
The more soluble compounds will be carried by the mobile phase the further up the plate, whereas the less soluble compounds, the higher affinity for the stationary phase will be left behind on the TLC plate.

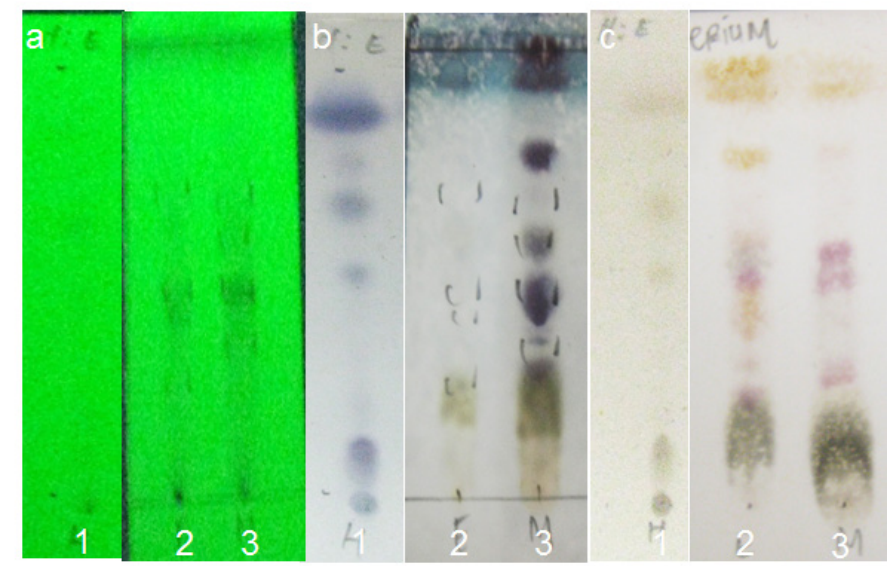

Figure 2. Chromatograms of D. gigas extracts: (1) n-hexane extract developed with an eluent system of hexane:ethyl acetate (9:1), (2) ethanolic and (3) methanolic extracts developed with an eluent system of chloroform:methanol:water (6:4:1), (a) viewed under $254 \mathrm{~nm}$, (b) sprayed with $1 \%$ vanillin-sulphuric acid, (c) sprayed with $1 \%$ cerium (IV) sulfate).

\section{Antioxidant Activity}

The qualitative analysis of antioxidant was carried out by the TLC-bioautography on DPPH radical scavenging activity. The TLC-chromatogram (Figure 3) showed the yellow spot on the purple background.

DPPH free radical is most extensively used to evaluate antioxidant activity because it is a stable free radical. The yellow spot on the purple background indicated the presence of the antioxidant activity of the extract (Wang et al., 2012). Based on the result, it indicated that all of the D. gigas extracts had antioxidant activity. The antioxidant capacity was indicated by the intensity of the yellow color. The extracts were furthermore analyzed by a quantitative method to determine their potential as an antioxidant. The parameter used in antioxidant activity assay was $\mathrm{IC}_{50}$, defined as Jurnal Biodjati 4(2):263-277, November 2019 the amount of extract concentration required to produce a $50 \%$ reduction of DPPH free radical (Molyneux, 2004). The extract concentration and the IC values giving the linear regression equation was used to calculate the $\mathrm{IC}_{50}$ value. A calibration curve in the linear by plotting the extract concentration vs the IC value gave a positive correlation coefficient (Figure 4), indicating that the more antioxidant compounds in the extract, the more the ability to reduce free radical activity.

The results showed that the ethanolic extract of $D$. gigas exhibited the highest antioxidant activity with an $\mathrm{IC}_{50}$ value of $(89.16 \pm 0.0219 \mu \mathrm{g} / \mathrm{mL})$ followed by methanolic extract $(90.72 \pm 0.0894 \mu \mathrm{g} / \mathrm{mL})$ and n-hexane extract $(336.18 \pm 0.0984 \mu \mathrm{g} / \mathrm{mL})$. $(+)$-Catechin as a positive control has an $\mathrm{IC}_{50}$ value of $2.03 \pm 0.1115$ (Table 1 ). 


\section{JURNAL BIDDJATI}

http://journal.uinsgd.ac.id/index.php/biodjati

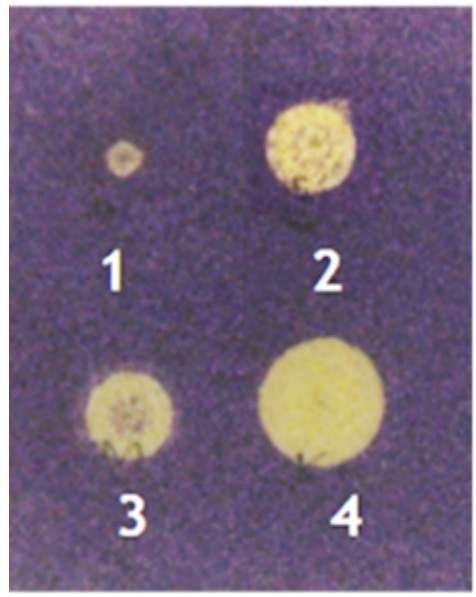

Figure 3. Bioautography of antioxidant activity of $D$. gigas: (1) n-hexane extract, (2) ethanolic extract, (3) methanolic extract and (4) (+)-catechin.

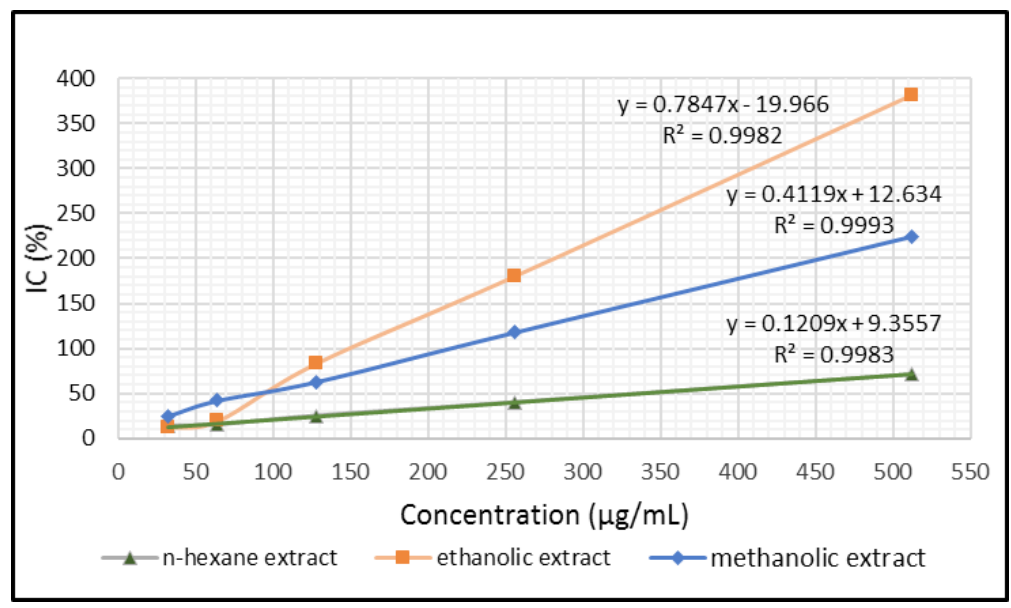

Figure 4. Linear correlation between the extract concentration of $D$. gigas and the IC(\%).

Table 1. Antioxidant Activity Index (AAI) and the $\mathrm{IC}_{50}$ value of D. gigas extracts

\begin{tabular}{cccc}
\hline No & Sample & $\mathrm{IC}_{50}(\mu \mathrm{g} / \mathrm{mL})$ & AAI \\
\hline 1 & n-Hexane extract & $336.18 \pm 0.0984$ & 0.09 \\
2 & Ethanolic extract & $89.16 \pm 0.0219$ & 0.34 \\
3 & Methanolic extract & $90.72 \pm 0.0894$ & 0.33 \\
4 & $(+)$-Catechin & $2.03 \pm 0.1115$ & 15.18 \\
\hline
\end{tabular}

The $\mathrm{IC}_{50}$ values were represented as the means \pm standard deviation

The classification of the antioxidant activity of extracts is presented in Table 2. Based on AAI values, those of three extracts were classified as moderate antioxidants, while $(+)$-catechin showed very strong antioxidant properties. This indicates that the lower the value of $\mathrm{IC}_{50}$, the higher the antioxidant activity index (Molyneux, 2004). The AAI values for the ethanolic and methanolic extracts were higher than that of the n-hexane extract. The difference in antioxidant activity is caused by the efficiency of solvents in extracting antioxidant compounds. Polar solvents such as eth- anol and methanol can attract more chemical compounds that might have antioxidant activity than non-polar solvents such as n-hexane.

The extracts showed lower antioxidant activity than the positive control (+)-Catechin. This can be explained that the positive control used is in purified form, while the extracts are the mixtures of chemical compounds. The mixture of chemical compounds in the extracts may neutralize, inhibit, or produce additive or synergistic effects by helping enhance the potential of the active compounds (Dhankhar et al., 2012). 


\section{JURNAL BIDDJATI}

http://journal.uinsgd.ac.id/index.php/biodjati

Table 2. The Classification of Antioxidant Activity for Extracts (Scherer \& Godoy, 2009)

\begin{tabular}{cc}
\hline Antioxidant Activity Index (AAI) & Antioxidant Activity \\
\hline$<0.05$ & Poor \\
$0.05-1.00$ & Moderate \\
$1.00-2.00$ & Strong \\
$>2.00$ & Very strong \\
\hline
\end{tabular}

\section{Antibacterial Activity}

The qualitative analysis of antibacterial activity against $S$. aureus and $E$. coli were carried out by the TLC-bioautography method. The results showed that the ethanolic and methanolic extracts could only inhibit the growth $S$. aureus with various inhibition zone diameters, and chloramphenicol as a positive control was active against both $S$. aureus and E. coli (Figure 5).

The inhibition of bacterial growth was indicated by the formation of clear white zones around the extract (Das et al., 2010). The purple color on the TLC plate after being sprayed with iodonitrotetrazolium salt (INT) was caused by the reaction of dehydrogenase enzyme in living microorganisms that converts INT to purple formazan (Silva et al., 2005). Chloramphenicol was used as a positive control in the antibacterial activity assay, due to its broad-spectrum activity with MIC range of 1-90 $\mu \mathrm{g} / \mathrm{mL}$ (Adetutu et al., 2011).

The antibacterial activity of the extracts was further analyzed quantitatively by determining the MIC value against $S$. aureus and E. coli. The lowest extract concentration that can inhibit the growth of bacteria is defined as MIC. The MIC values were $>625,625$ and $625 \mu \mathrm{g} / \mathrm{mL}$ for $\mathrm{n}$-hexane, ethanolic and methanolic extracts respectively against $S$. aureus, while MIC values against E.coli were $>625$ $\mu \mathrm{g} / \mathrm{mL}$ for all extracts. Chloramphenicol has a MIC value of $4 \mu \mathrm{g} / \mathrm{mL}$ against both reference bacteria (Table 3 ). Based on the classification of antibacterial activity in Table 4, it can be concluded that all of the extracts presented weak activity against $S$. aureus and E.coli, while chloramphenicol exhibit significant antibacterial activity against all tested bacteria.
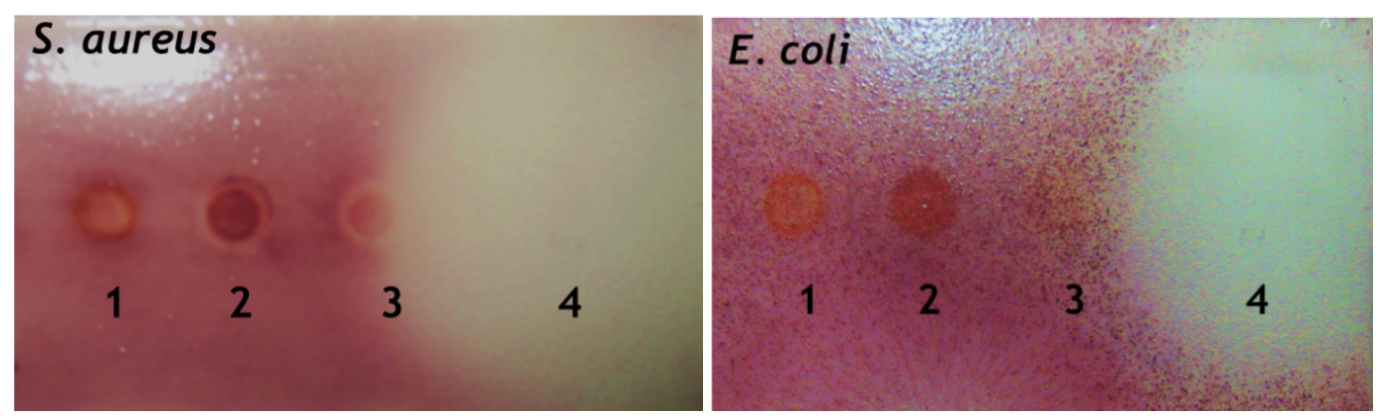

Figure 5. Bioautography of antibacterial activity of $D$. gigas against $S$. aureus (left) and $E$. coli (right): (1) n-hexane extract, (2) ethanolic extract, (3) methanolic extract, and (4) chloramphenicol. 
Jurnal Biodjati 4(2):263-277, November 2019

\section{JURNAL BIDDJATI}

http://journal.uinsgd.ac.id/index.php/biodjati

Table 3. The Minimum Inhibitory Concentrations (MIC) of D. gigas extracts

\begin{tabular}{cccc}
\hline \multirow{2}{*}{ No } & Sample & \multicolumn{2}{c}{ MIC $(\mu \mathrm{g} / \mathrm{mL})$} \\
\cline { 3 - 4 } & & S. aureus & E. coli \\
\hline 1 & n-Hexane extract & $>625$ & $>625$ \\
2 & Ethanolic extract & 625 & $>625$ \\
3 & Methanolic extract & 625 & $>625$ \\
4 & Chloramphenicol & 4 & 4 \\
\hline
\end{tabular}

Table 4. The Classification of Antibacterial Activity for Extracts (Pessini et al., 2003)

\begin{tabular}{cc}
\hline MIC $(\mu \mathrm{g} / \mathrm{ml})$ & Antibacterial Activity \\
\hline$<100$ & Strong \\
$100-500$ & Moderate \\
$500-1000$ & Weak \\
$>1000$ & Inactive \\
\hline
\end{tabular}

In the present study, the extracts were more effective against S.aureus than E.coli. The difference in sensitivity between two types of Gram bacteria may be associated with the differences in the morphology and molecular components of membranes. The presence of the additional protection provided by the outer membrane layer contains lipopolysaccharide in Gram-negative bacteria that make this bacterium tend to be less permeable to antibacterial substances than Gram-positive bacteria (Epand et al., 2016).

\section{GC-MS Profiling of $\boldsymbol{D}$. gigas Extract}

The identification of chemical compounds of $D$. gigas extract was carried out using GC-MS (Figure 6).

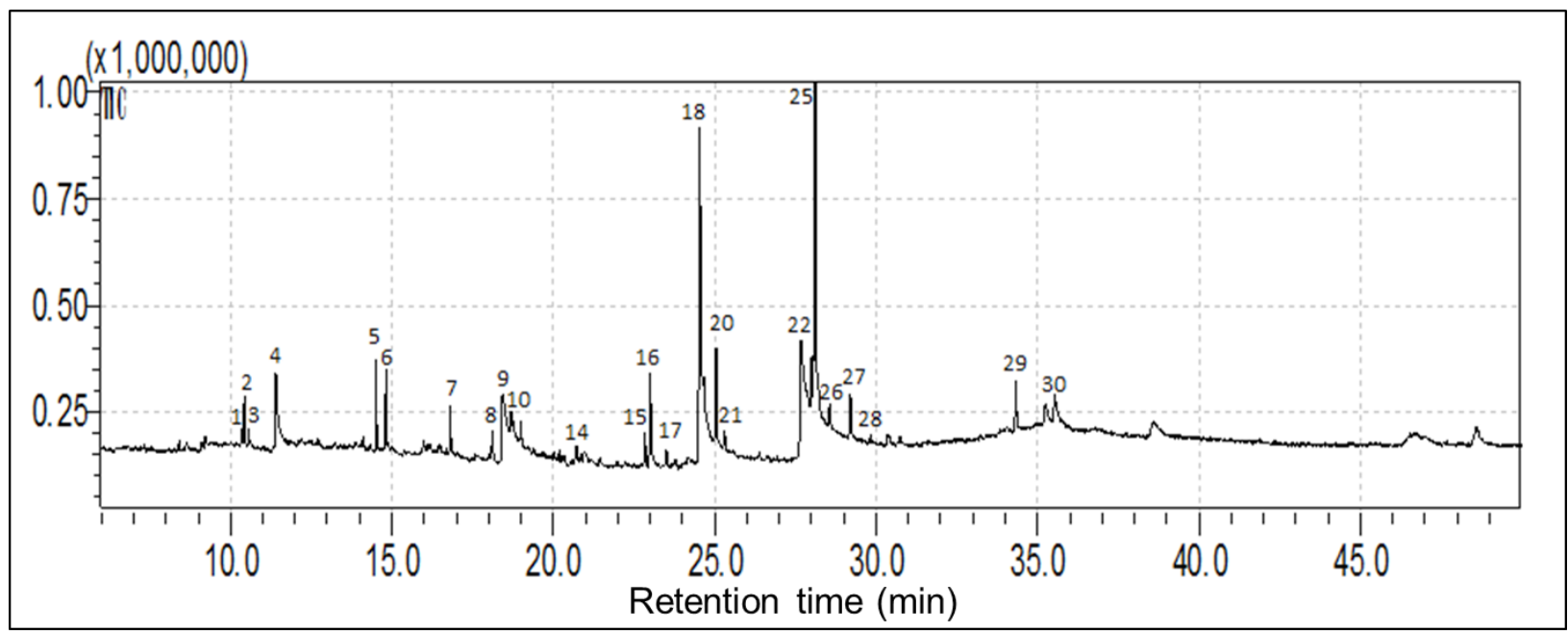

Figure 6. GC-MS chromatogram of the ethanolic extract of D. gigas. The peak numbers correspond to the numbers in Table 5. 
Jurnal Biodjati 4(2):263-277, November 2019

\section{JURNAL BIDDJATI}

http://journal.uinsgd.ac.id/index.php/biodjati

Table 5. Chemical compounds of ethanol extract of D. gigas

\begin{tabular}{|c|c|c|c|c|c|}
\hline $\begin{array}{c}\text { Peak } \\
\text { no. }\end{array}$ & $\begin{array}{c}\text { Retention } \\
\text { time (min) }\end{array}$ & Area & $\begin{array}{c}\text { Area Percentage } \\
(\%) \\
\end{array}$ & Chemical Compounds & Activity \\
\hline 1 & 10.338 & 93120 & 0.51 & Hexamethylcyclotrisiloxane & \\
\hline 2 & 10.428 & 205998 & 1.13 & Undecane & $\begin{array}{l}\text { Alarm pheromone (Mizu- } \\
\text { nami et al., 2010) }\end{array}$ \\
\hline 3 & 10.555 & 78734 & 0.43 & L-Leucine, ethyl ester & \\
\hline 4 & 11.402 & 541613 & 2.96 & $\begin{array}{l}\text { 2,3-dihydro-3,5-dihydroxy-6- } \\
\text { methyl-4(H)-Pyran-4-one }\end{array}$ & $\begin{array}{l}\text { Antioxidant (Kanzler et } \\
\text { al., 2016); anti-inflamma- } \\
\text { tory, antiproliferative, an- } \\
\text { timicrobial (Velayutham } \\
\text { \& Karthi, 2015); trail } \\
\text { pheromone (Cerda et al., } \\
\text { 2014) }\end{array}$ \\
\hline 5 & 14.517 & 353827 & 1.93 & $\begin{array}{l}\text { Propanoic acid, 2-methyl-, } \\
\text { 2,2-dimethyl-1-(2-hydroxy-1- } \\
\text { methyl ethyl)propyl ester }\end{array}$ & $\begin{array}{l}\text { Fungicide and bactericide } \\
\text { (Haque et al., 2009) }\end{array}$ \\
\hline 6 & 14.808 & 318514 & 1.74 & $\begin{array}{l}\text { Propanoic acid, 2-methyl-, } \\
\text { 3-hydroxy-2,4,4-trimethyl } \\
\text { pentyl ester }\end{array}$ & $\begin{array}{l}\text { Fungicide and bactericide } \\
\text { (Haque et al., 2009) }\end{array}$ \\
\hline 7 & 16.808 & 209939 & 1.15 & $\begin{array}{l}\text { Butylated Hydroxytoluene } \\
\text { (BHT) }\end{array}$ & $\begin{array}{l}\text { Antioxidant (Bouftira et } \\
\text { al., 2007; Ibtissem et al., } \\
\text { 2010) }\end{array}$ \\
\hline 8 & 18.106 & 151704 & 0.83 & $\begin{array}{l}\text { Propanoic acid, 2-methyl-, } \\
\text { 1-(1,1-dimethylethyl)-2-me- } \\
\text { thyl-1,3-propanediyl ester }\end{array}$ & \\
\hline 9 & 18.433 & 776299 & 4.24 & Ethyl alpha-d-glucopyranoside & $\begin{array}{l}\text { Antituberculous, antioxi- } \\
\text { dant, alpha } \\
\text { amylase inhibitor, } \\
\text { hypolipidemic, anticon- } \\
\text { vulsant (Velayutham \& } \\
\text { Karthi, 2015) }\end{array}$ \\
\hline 10 & 18.688 & 144380 & 0.79 & $\begin{array}{l}\text { 3-(2,3-epoxypropoxy)propyl] } \\
\text { ethoxydimethyl-silane }\end{array}$ & \\
\hline 11 & 18.775 & 110983 & 0.61 & Benzophenone & $\begin{array}{l}\text { Anti-HIV, antioxidant, } \\
\text { antiviral, antimicrobial, } \\
\text { antifungal, and cytotoxic } \\
\text { (Wu et al., 2014) }\end{array}$ \\
\hline 12 & 18.994 & 108350 & 0.59 & Tributyl phosphate & \\
\hline 13 & 20.175 & 46987 & 0.26 & 4-(1,1-dimethylpropyl)-phenol & Antioxidant (Foti, 2007) \\
\hline 14 & 20.725 & 82338 & 0.45 & Diallyl phthalate & \\
\hline 15 & 22.838 & 215304 & 1.18 & $\begin{array}{l}\text { 1,2-Benzenedicarboxylic acid, } \\
\text { bis(2-methylpropyl) ester }\end{array}$ & \\
\hline 16 & 22.997 & 589189 & 3.22 & 1-Hexadecanol & $\begin{array}{l}\text { Antimycoplasma (Fletch- } \\
\text { er et al., 1981) }\end{array}$ \\
\hline
\end{tabular}


Jurnal Biodjati 4(2):263-277, November 2019

\section{JURNAL BIDDJATI}

http://journal.uinsgd.ac.id/index.php/biodjati

\begin{tabular}{|c|c|c|c|c|c|}
\hline $\begin{array}{c}\text { Peak } \\
\text { no. }\end{array}$ & $\begin{array}{l}\text { Retention } \\
\text { time (min) }\end{array}$ & Area & $\begin{array}{c}\text { Area Percentage } \\
(\%) \\
\end{array}$ & Chemical Compounds & Activity \\
\hline 17 & 23.501 & 121700 & 0.66 & Lidocaine & \\
\hline 18 & 24.532 & 3210902 & 17.54 & n-Hexadecanoic acid & $\begin{array}{l}\text { Antiinflammatory } \\
\text { (Aparna et al., 2012), } \\
\text { antioxidants, hypocholes- } \\
\text { terolemic, nematicide, } 5 \\
\text { alpha-reductase inhibitors, } \\
\text { antiandrogenic, flavor, } \\
\text { hemolytic (Kumar et al., } \\
\text { 2010; Tyagi \& Agarwal, } \\
\text { 2017), and larvicidal ac- } \\
\text { tivity against mosquitoes } \\
\text { (Rahuman et al., 2000) }\end{array}$ \\
\hline 19 & 24.659 & 518424 & 2.83 & Ethyl 9-hexadecenoate & \\
\hline 20 & 25.041 & 633219 & 3.46 & Hexadecanoic acid, ethyl ester & $\begin{array}{l}\text { Antioxidant, hemolytic, } \\
\text { hypocholesterolemic, ne- } \\
\text { maticide, antiandrogenic } \\
\text { (Tyagi \& Agarwal, 2017) }\end{array}$ \\
\hline 21 & 25.303 & 137598 & 0.75 & $\begin{array}{l}\text { Butanoic acid, } \\
\text { 2-[2,4-bis(1,1-dimethylpropyl) } \\
\text { phenoxy]- }\end{array}$ & \\
\hline 22 & 27.68 & 1948564 & 10.65 & Bis(2-ethylhexyl) maleate & $\begin{array}{l}\text { Cancer preventive, } \\
\text { antiandrogenic (Ma'arif } \\
\text { et al., 2016), antioxidant } \\
\text { (Wei et al., 2016), anti-in- } \\
\text { flammatory, dermatiti- } \\
\text { genic, } 5 \text { alpha-reductase } \\
\text { inhibitors, anemiagenic, } \\
\text { hypocholesterolemic } \\
\text { (Vadivel \& Gopalakr- } \\
\text { ishnan, 2011) }\end{array}$ \\
\hline 24 & 28.002 & 661775 & 3.62 & Linoleic acid ethyl ester & $\begin{array}{l}\text { Antiarthritic, antiandro- } \\
\text { genic, } 5 \text { alpha-reductase } \\
\text { inhibitor, hypocholester- } \\
\text { olemic, antiacne, nemat- } \\
\text { icide (Tyagi \& Agarwal, } \\
\text { 2017) }\end{array}$ \\
\hline 25 & 28.103 & 5450469 & 29.78 & Ethyl Oleate & $\begin{array}{l}\text { Primer pheromone (Cas- } \\
\text { tillo et al., 2012), flavor } \\
\text { (Duke, 2016) }\end{array}$ \\
\hline 26 & 28.56 & 144783 & 0.79 & Octadecanoic acid, ethyl ester & \\
\hline 27 & 29.197 & 329007 & 1.8 & $\begin{array}{l}\text { 2-Butenedioic acid (E)-, } \\
\text { bis(2-ethylhexyl) ester }\end{array}$ & $\begin{array}{l}\text { Antidermatitic, antioxi- } \\
\text { dant, antihepatocarcino- } \\
\text { genic, antioxidant, antitu- } \\
\text { mor, flavor (Duke, 2016) }\end{array}$ \\
\hline 28 & 29.819 & 57305 & 0.31 & Tributyl acetylcitrate & \\
\hline 29 & 34.326 & 353802 & 1.93 & Bis(2-ethylhexyl) phthalate & \\
\hline 30 & 35.53 & 145877 & 0.8 & $\begin{array}{l}\text { 1-Cyclohexyl-2-methyl-prop-2- } \\
\text { en-1-one }\end{array}$ & \\
\hline
\end{tabular}




\section{JURNAL BIDDJATI}

http://journal.uinsgd.ac.id/index.php/biodjati

The major chemical compounds in the ethanolic extract of D. gigas are saturated and unsaturated fatty acids. Three major compounds are ethyl oleate (29.78\%), n-hexadecenoic acid (17.54\%), and oleic acid $(10.65 \%)$. Those chemical compounds were also identified in a traditional edible insect species in China, Polyrhachis vicina Roger (Edible black ant) (Shen et al., 2006).

The GC-MS analysis revealed that BHT, a lipophilic organic compound (fat-soluble) which is commonly used as a synthetic antioxidant for cosmetics, food additive, and pharmaceuticals occurs naturally in the ethanolic extract of D. gigas. This result of the study is corresponding to Bouftira et al. (2007) and Ibtissem et al. (2010), that BHT occurs naturally in Mesembryanthemum crystallinum (the purple leaves of the halophyte plant).

This finding also showed that undecane was found in the ethanolic extract of $D$. gigas. Undecane is an alkane hydrocarbon with the chemical formula $\mathrm{CH}_{3}\left(\mathrm{CH}_{2}\right)_{9} \mathrm{CH}_{3}$. Many formicine species utilize this compound as an alarm pheromone (Lenz et al., 2012). Alarm pheromone plays an important role in defense of the colony in ants. A study by Mizunami et al. (2010) reported that formic acid and undecane were alarm pheromone compounds of workers of the carpenter ant Camponotus obscureipes.

One pair of isomers, propanoic acid 2-methyl-,2,2-dimethyl-1-(2-hydroxy-1methyl ethyl)propyl ester and propanoic acid, 2-methyl-,3-hydroxy-2,4,4-trimethyl pentyl ester, reported for this species. Propanoic acid is a weak acid that has been proven to show efficacy in inhibiting the growth of fungi (Aspergillus flavus, A. niger, A. versicolor, Chaetomium globosum, Penicillium funiculosum, $P$. expansum, $P$. spinulosum, $P$. roqueforti), bacteria (Aerobacter aerogenes, Bacillus subtilis, Escherichia coli, E. freundii, Staphylococcus aureus, Serratia marcescens, Pseudomonas aeroginosa, P. fluorescens, Proteus vulgaris) and yeast (Candida albicans, C. krusel, Mansenula anomala, Pichia fermentans, Oidinum sp., Saccharomyces cerevisiae, S. vini) (Haque et al., 2009).

The antioxidant activity of the ethanolic extract of $D$. gigas may be attributed to the presence of flavonoids (2,3-dihydro-3,5-dihydroxy-6-methyl-4H-pyran-4-one), phenolic compounds [4-(1,1-dimethyl propyl)phenol], butylated hydroxytoluene (BHT), and fatty acids. BHT is an additive that is often used in foods and cosmetics to prevent oxidative rancidity. BHT is usually intended to prevent the appearance of ketones and aldehydes which can give unpleasant odor products into cosmetics (such as bronzing agents, creams, make-up removers, eyelift products, oils, lotions, and sunscreens) (Capitan-vallvey et al., 2002). Fatty acids are mainly used in cosmetic products as an emulsifier and the production of soap (Kelm \& Wickett, 2017). This present study showed that the ethanolic extract of $D$. gigas may contain valuable bioactive compounds exhibited antioxidant and antibacterial activity. This is the first study related to antibacterial and antioxidant activities as well as GC-MS analysis of an extract of giant forest ant $D$. gigas.

\section{ACKNOWLEDGEMENTS}

We thank you for financial support for this work from the DIPA-Research Center for Biology, Indonesian Institute of Sciences. Also, we thank Mr. Ratno, Wanariset Samboja, who helped collect the samples (ants), and Mr. Andi Saptadji Kamal for his help in the laboratory works. 


\section{JURNAL BIDDJATI}

http://journal.uinsgd.ac.id/index.php/biodjati

\section{REFERENCES}

Adetutu, A., Morgan, W. A. \& Corcoran, O. (2011). Antibacterial, Antioxidant and Fibroblast Growth Stimulation Activity of Crude Extracts of Bridelia ferruginea Leaf, a Wound-Healing Plant of Nigeria. Journal of Ethnopharmacology, 133, 116-119.

Aparna, V., Kalarickal, V. \& Mandal, P. K. (2012). Anti-Inflammatory Property of n-Hexadecanoic Acid: Structural Evidence and Kinetic Assessment. Chem Biol Drug Des, 80(3), 434-439.

Badr, G., Garraud, O., Daghestani, M., Al-khalifa, M. S. \& Richard, Y. (2012). Human Breast Carcinoma Cells are Induced to Apoptosis by Samsum Ant Venom Through an IGF-1-Dependant pathway, PI3K/AKT and ERK signaling. Cellular Immunology, 273, 10-16.

Bot, A. N. M., Lechner, D. O., Finster, K., Maile, R. \& Boomsma, J. J. (2002). Variable Sensitivity of Fungi and Bacteria to Compounds Produced by the Metapleural Glands of Leaf-Cutting Ants. Insectes Soc., 49, 363-370.

Bouftira, I., Abdelly, C. \& Sfar, S. (2007). Identification of a Naturally Occurring 2,6-bis(1.1-dimethylethyl)-4-methylphenol from Purple Leaves of the Halophyte Plant Mesembryanthemum crystallinum. African Journal of Biotechnology, 6(9), 1136-1139.

Capitan-vallvey, L. F., Valencia, Mequias, C. \& Nicolas, E. A. (2002). Flow-through Sensor for Determination of Butylated Hydroxytoluene in Cosmetics. Analytical Letters, 35(1), 65-81.

Castillo, C., Chen, H., Graves, C., Maisonnasse, A., Le, Y. \& Plettner, E. (2012). Biosynthesis of Ethyl Oleat, a Primer Pheromone, in the Honey Bee (Apis mellifera L .). Insect Biochemistry and Molecular Biology, 42(6), 404-416.

Cerda, X., Oudenhove, L. Van, Bernstein, C., \& Boulay, R. R. (2014). A List of and Some Comments about the Trail Pheromones of Ants. Natural Product Communications, 9(8), 1115-1122.

Das, K., Tiwari, R. K. S. \& Shrivastava, D. K. (2010). Techniques for Evaluation of Medicinal Plant Products as Antimicrobial Agent: Current Methods and Future Trends. Journal of Medicinal Plants Research, 4(2), 104-111.

Dewanjee, S., Gangopadhyay, M., Bhattacharya, N., Khanra, R. \& Dua, T. K. (2015). Bioautography and its Scope in the Field of Natural Product Chemistry. Journal of Pharmaceutical Analysis, 5(2), 75-84.

Dhankhar, S., Kumar, S., Dhankhar, S. \& Yadav, J. P. (2012). Antioxidant Activity of Fungal Endophytes Isolated From Salvadora oleoides Decne. Int J Pharm Pharm Sci., 4(2), 380-385.

Ebaid, H., Al-khalifa, M., Isa, A. M. \& Gadoa, S. (2012). Bioactivity of Samsum ant (Pachycondyla sennaarensis ) Venom Against Lipopolysaccharides Through Antioxidant and Upregulation of Akt1 Signaling in Rats. Lipids in Health and Disease, 11(93), 1-10.

Ebaid, H., Al-tamimi, J., Hassan, I., Alhazza, I., \& Al-khalifa, M. (2014). Antioxidant Bioactivity of Samsum Ant (Pachycondyla sennaarensis) Venom Protects against CCL 4 -Induced Nephrotoxicity in Mice. Oxidative Medicine and Cellular Longevity, 1-9.

Epand, R. M., Walker, C., Epand, R. F., \& Magarvey, N. A. (2016). Molecular Mechanisms of Membrane Targeting Antibiotics. BBA - Biomembranes, 1858(5), 980-987. 


\section{JURNAL BIDDJATI}

http://journal.uinsgd.ac.id/index.php/biodjati

Falotico, T., Labruna, M. B., Verderane, M. P., De Resende, B. D., Izar, P. \& Ottoni, E. B. (2007). Repellent Efficacy of Formic Acid and the Abdominal Secretion of Carpenter Ants (Hymenoptera: Formicidae ) Against Amblyomma Ticks) Aca. J. Med. Entomol, 44(4), 718-721.

Fletcher, R. D., Gilbertson, J. R., Albers, A. C. \& White, J. D. (1981). Inactivation of Mycoplasmas by Long-Chain Alcohols. Antimicrob. Agents Chemother, 19(5), 917-921.

Foti, M. C. (2007). Antioxidant Properties of Phenols. Journal of Pharmacy and Pharmacology, 59, 1673-1685.

Haque, M. N., Chowdhury, R., Islam, K. M. S. \& Akbar, M. A. (2009). Propionic Acid is an Alternative to Antibiotics in Poultry Diet. Bang. J. Anim. Sci., 38(1\&2), 115-122.

Ibtissem, B., Imen, M. \& Souad, S. (2010). Dosage of 2,6-Bis (1.1-Dimethylethyl)-4-Methylphenol (BHT) in the Plant Extract Mesembryanthemum crystallinum. Journal of Biomedicine and Biotechnology, 1-5.

Inagaki, H., Akagi, M., Imai, H. T., Taylor, R. W. \& Kubo, T. (2004). Molecular Cloning and Biological Characterization of Novel Antimicrobial Peptides, Pilosulin 3 and Pilosulin 4, from a Species of the Australian Ant Genus Myrmecia. Archives of Biochemistry and Biophysics, 428, 170-178.

Johnson, R. N., Agapow, P.-M., \& Crozier, R. H. (2003). A Tree Island Approach to Inferring Phylogeny in the Ant Subfamily Formicinae, with Especial Reference to the Evolution of Weaving. Molecular Phylogenetics and Evolution, 29, 317330.

Kanzler, C., Haase, P. T., Schestkowa, H. \& Kroh, L. W. (2016). Antioxidant Prop- erties of Heterocyclic Intermediates of the Maillard Reaction and Structurally Related Compounds. J. Agric. Food Chem, 64, 7829-7837.

Kelm, G. R. \& Wickett, R. R. (2017). The Role of Fatty Acids in Cosmetic Technology. Fatty Acids. Elsevier Inc.

Kumar, P. P., Kumaravel, S. \& Lalitha, C. (2010). Screening of Antioxidant Activity, Total Phenolics and GC-MS Study of Vitex negundo. Afr. J. Biochem. Res., 4(7), 191-195.

Lenz, E. L., Krasnec, M. O. \& Breed, M. D. (2012). Identification of Undecane as an Alarm Pheromone of the Ant Formica argentea. J Insect Behav, 26, 101-108.

Ma'arif, B., Agil, M. \& Laswati, H. (2016). Phytochemical Assesment on n-Hexane Extract and Fractions of Marsilea crenata Presl. Leaves Through GC-MS. Trad. Med. J., 21(2), 77-85.

Marin, H. F., Zimmerman, J. K., Rehner, S. A. \& Wcislo, W. T. (2006). Active Use of the Metapleural Glands by Ants in Controlling Fungal Infection. Proc. R. Soc. $B, 273,1689-1695$.

Mendonca, A. de L., da Silva, C. E., de Mesquita, F. L. T., da Silva Campos, Rousseau Do Nascimento, R. R., de Azevedo Ximenes, E. C. P. \& Sant Ana, A. E. G. (2009). Antimicrobial Activities of Components of the Glandular Secretions of Leaf Cutting Ants of the Genus Atta. Antonie van Leeuwenhoek, 95, 295-303.

Mizunami, M., Yamagata, N. \& Nishino, H. (2010). Alarm Pheromone Processing in the Ant Brain: an Evolutionary Perspective. Frontiers in Behavioral Neuroscience, 4, 1-9.

Molyneux, P. (2004). The Use of the Stable Free Radical diphenylpicryl-hydrazyl (DPPH) for Estimating Antioxidant Ac- 


\section{JURNAL BIDDJATI}

http://journal.uinsgd.ac.id/index.php/biodjati

tivity. Songklanakarin J. Sci. Technol., 26(2), 211-219.

Moreau, S. J. M. (2013). 'It stings a bit but it cleans well': Venoms of Hymenoptera and their Antimicrobial Potential. Journal of Insect Physiology, 59, 186-204.

Orivel, J., Redeker, V., Caer, L., Krier, F., Longeon, A., Dejean, A., ... Rossier, J. (2001). Ponericins, New Antibacterial and Insecticidal Peptides from the Venom of the Ant Pachycondyla goeldii. J.Biol. Chem, 276(21), 17823-17829.

Pessini, G. L., Filho, B. P. D., Nakamura, C. V. \& Cortez, D. A. G. (2003). Antibacterial Activity of Extracts and Neolignans from Piper regnellii (Miq.) C. DC. var. pallescens (C.DC.) Yunck. Mem Inst Oswaldo Cruz, 98(8), 1115-1120.

Pfeiffer, M. \& Linsenmair, K. E. (2007). Trophobiosis in a Tropical Rainforest on Borneo: Giant Ants Camponotus gigas (Hymenoptera: Formicidae ) Herd Wax Cicadas Bythopsyrna circulata (Auchenorrhyncha: Flatidae). Asian Myrmecology, 1, 105-119.

Rahuman, A. A., Gopalakrishnan, G., Ghouse, S., Arumugam, S. \& Himalayan, B. (2000). Effect of Feronia limonia on Mosquito Larvae. Fitoterapia, 71, 553 555.

Scherer, R., \& Godoy, H. T. (2009). Antioxidant activity index (AAI) by the 2,2-diphenyl-1-picrylhydrazyl method. Food Chemistry, 112, 654-658.

Shen, L., Li, D., Feng, F. \& Ren, Y. (2006). Nutritional Composition of Polyrhachis vicina Roger (Edible Chinese Black ant). Songklanakarin J.Sci. Technol., 28, 107-114.

Silva, M. T. G., Simas, S. M., Batista, T. G. F. M., Cardarelli, P. \& Tomassini, T. C. B. (2005). Studies on Antimicrobial Activity, in vitro, of Physalis angulata
L . (Solanaceae) Fraction and Physalin B Bringing out the Importance of Assay Determination. Mem Inst Oswaldo Cruz, 100(7), 779-782.

Stow, A. \& Beattie, A. (2008). Chemical and Genetic Defenses Against Disease in Insect Societies. Brain, Behavior and Immunity, 22, 1009-1013.

Sullivan, D. C., Flowers, H., Rockhold, R., Herath, H. M. T. B. \& Nanayakkara, N. P. D. (2009). Antibacterial Activity of Synthetic Fire Ant Venom: The Solenopsins and Isosolenopsins. The American Journal of the Medical Sciences, 338(4), 287-291.

Takao, L. K., Imatomi, M. \& Gualtieri, S. C. J. (2015). Antioxidant Activity and Phenolic Content of Leaf Infusions of Myrtaceae species from Cerrado (Brazilian Savanna). Braz. J. Biol., 75(4), 948-952.

Tragust, S., Mitteregger, B., Barone, V., Konrad, M. \& Ugelvig, L. V. (2013). Ants Disinfect Fungus-Exposed Brood by Oral Uptake and Spread of Their Poison. Current Biology, 23(1), 76-82.

Tranter, C. \& Hughes, W. O. H. (2015). Acid, Silk and Grooming: Alternative Strategies in Social Immunity in Ants? Behav Ecol Sociobol, 69, 1687-1699.

Tyagi, T. \& Agarwal, M. (2017). Phytochemical Screening and GC-MS Analysis of Bioactive Constituents in the E-thanolic extract of Pistia stratiotes L . and Eichhornia crassipes ( Mart.) solms. Journal of Pharmacognosy and Phytochemistry, 6(1), 195-206.

Vadivel, E. \& Gopalakrishnan, S. B. (2011). GC-MS analysis of some bioactive constituents of Mussaenda frondosa Linn. International Journal of Pharma and Bio Sciences, 2(1), 313-320.

Velayutham, P. \& Karthi, C. (2015). GC-MS 


\section{JURNAL BIDDJATI}

http://journal.uinsgd.ac.id/index.php/biodjati

Profile of In Vivo, In Vitro and Fungal Elicited In Vitro Leaves of Hybanthus Enneaspermus ( L .) F. MUELL. Int $J$ Pharm Pharm Sci., 7(10), 260-267.

Vicas, S. I., Rugina, D. \& Socaciu, C. (2012). Antioxidant Activity of European Mistletoe Viscus album Phytochemicals as Nutraceuticals- Global Approaches to Their Role in Nutrition and Health. (V. Rao, Ed.). Rijeka, Croatia: InTech.

Wang, J., Yue, Y.-D., Tang, F. \& Sun, J. (2012). TLC Screening for Antioxidant Activity of Extracts from Fifteen Bamboo Species and Identification of Antioxidant Flavone Glycosides from Leaves of Bambusa. textilis McClure. Molecules, 17, 12297-12311.

Wei, C., Yen, P., Chang, S., Cheng, P. \& Lo, Y. (2016). Antioxidative Activities of Both Oleic Acid and Camellia tenuifolia Seed Oil Are Regulated by the Transcription Factor DAF- 16 / FOXO in Caenorhabditis elegans. PLoS ONE, 11(6), 1-15.
Wilsanand, V., Varghese, P. \& Rajitha, P. (2007). Therapeutics of insects and insect products in South Indian traditional medicine. Indian J Traditional Knowledge, 6(4), 563-568.

Wu, S., Long, C. \& Kennelly, E. J. (2014). Structural diversity and bioactivities of natural benzophenones. Nat. Prod. Rep., 31, 1158-1174.

Yek, S. H. \& Mueller, U. G. (2011). The Metapleural Gland of Ants. Biol. Rev., 86, 774-791.

Zeng, Y., Hu, X. P. \& Suh, S.-J. (2016). Characterization of Antibacterial Activities of Eastern Subterranean Termite, Reticulitermes flavipes, against Human Pathogens. PLoS ONE, 11(9), 1-17. 